\title{
Fabrication of Biosensors Using Vinyl Polymer-grafted Carbon Nanotubes
}

\author{
Seong-Ho Choi, Da-Jung Chung and Hai-Doo Kwen \\ Department of Chemistry, Hannam University, Daejeon 305-811, \\ Republic of Korea
}

\section{Introduction}

A biosensor is commonly defined as a device incorporating a bioreceptor connected to a transducer, which converts an observed response into a measurable signal proportional to analyte concentration which then is conveyed to a detector (Eggins, 1996). As demonstrated in Fig. 1, a biosensor consists of a bio-element and a sensor-element. A specific bio-element, including enzyme, antibody, microorganism, cell, and DNA, recognizes a specific analyte, and a sensor element transduces the change in the biomolecules into an electrical signal. Biosensors can be classified either by their bioreceptor or their transducer. Biosensors are known as enzymatic biosensors (enzymes), genosensors (DNAs), immunosensors (antibodies), etc. depending on the bioreceptors used. Biosensors can also be divided into several categories based on the transduction process, such as electrochemical, optical, piezoelectric, and thermal/calorimetric. Among these, electrochemical biosensors are the most widespread, numerous and successfully commercialized devices of biomolecular electronics (Dzyadevych et al., 2008).

Much literature on carbon nanotube (CNT)-based biosensors has been published over the past several years because CNTs have the following advantages: (1) small size with large surface area, (2) high sensitivity, (3) fast response time, (4) enhanced electron transfer and (5) easy protein immobilization on CNT-modified electrodes, coupled with the fact that several methods have been developed (J. Wang \& Musameh, 2003a; J. Wang et al., 2003b; Y. Saito et al., 1993). These properties make CNTs ideal for use in electrochemical biosensors and nanoscale electronic devices. Such potential applications would greatly benefit from CNTs in promoting the electron-transfer reaction of biomolecules, including catecholamine neurotransmitters (J. Wang et al., 2002a), cytochrome $c$ (J. Wang et al., 2002b), ascorbic acid (Z. H. Wang et al., 2002), NADH (Musameh et al., 2002), and hydrazine compounds (Zhao et al., 2002). The insolubility of CNTs in most solvents is a major barrier for developing such CNT-based biosensing devices. Therefore, surface modification is necessary for CNT materials to be biocompatible and to improve solubility in common solvents and selective binding capability to biotargets.

There are two main approaches for surface modification of CNTs: a non-covalent wrapping or adsorption and covalent chemical tethering. The non-covalent approach includes surfactant modification, polymer wrapping, and polymer absorption via various adsorption forces, such as van der Waals and $\Pi$-stacking interactions. The advantage of non-covalent modification is that the structures and mechanical properties of CNTs remain intact. 
However, the force between the CNTs and the wrapping molecules is very weak, which means that the load may not be transferred efficiently from the polymer matrix to the $\mathrm{CNT}$ filler (Islam et al., 2003). The covalent functionalization of CNT surfaces can improve the efficiency of load transfer from matrix to nanotubes. However, it must be noted that the process to obtain functional groups may introduce defects on the walls of nanotubes. These defects will lower the strength of the reinforcing component. Therefore, there will be a trade-off between the strength of the interface and the strength of the CNT filler (Eitan et al., 2003). The covalent functionalization of CNTs is most frequently initiated by introducing carboxylic acid groups using nitric acid oxidation (Men et al., 2008; J. Shen et al., 2007; Kitano et al., 2007). Thereafter, small molecules (Kooi et al., 2002; Liu, 2005; Tasis et al., 2003) or polymer chains (Kang \& Taton., 2003; O. K. Kim et al., 2003) can be chemically attached to the CNTs by esterification and amidation reactions via the carboxylic acid moieties. The chemical modification is an especially attractive target, as it can improve solubility (Bahr et al., 2001) and processing ability and allows the unique properties of CNTs to be coupled to other types of materials.

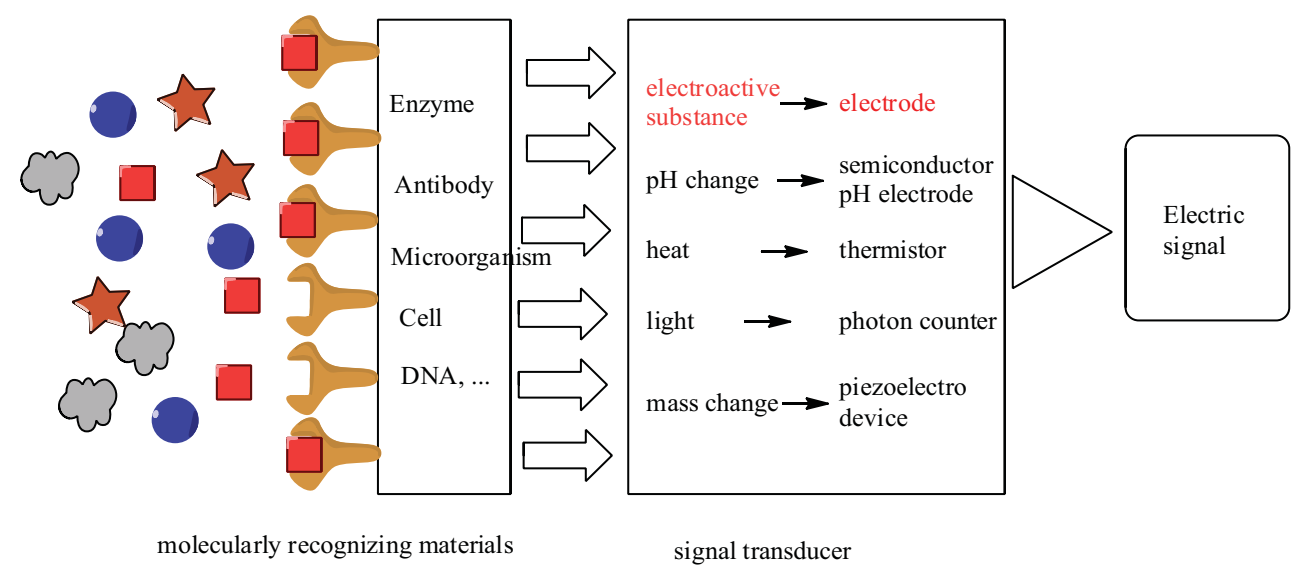

Fig. 1. Schematic diagram for the principal of the biosensors.

Radiation-induced graft polymerization (RIGP) is a useful method for the introduction of functional groups into polymer matrices using specially selected vinyl monomers. There have been several reports on RIGP of polar monomers onto the surface of polymer substrates with hydrophobic properties to obtain hydrophilic properties for versatile applications (Choi \& Nho, 1999a, 1999b; Choi et al., 1999, 2000a 2000b, 2001; S. K. Kim et al., 2010). RIGP can be easily modified for the surface of CNTs to induce free radicals on the surface of nanotubes in aqueous solution and organic solvents at room temperature. Figure 2 shows the introduction of functional groups, such as hydroxyl, carboxyl, and sulfonic acid onto the CNT surface (Oh et al., 2006a) and fullerene (Chung et al., 2011) using free radicals generated during $\gamma$-ray irradiation.

In this chapter, we describe the fabrication of biosensors using vinyl polymer-grafted carbon nanotubes prepared by RIGP. Various vinyl monomers used for functionalization of CNTs will be introduced. The obtained vinyl polymer-grafted CNTs are used as biosensor supporting materials to increase sensitivity and affinity for biomolecules. The characterization and application of the four biosensor types are: (1) Enzyme-free biosensors 
based on chemical reaction, (2) Enzymatic biosensors based on functional group-MWNTs, (3) Bacterial biosensors based on polymer grafted MWNTs, and (4) E-DNA biosensors based on polymer grafted MWNTs, as summarized in Fig. 3.

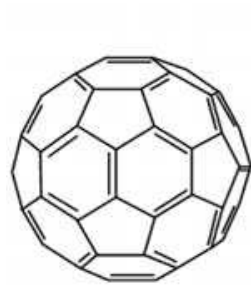

Fullerene (C60)

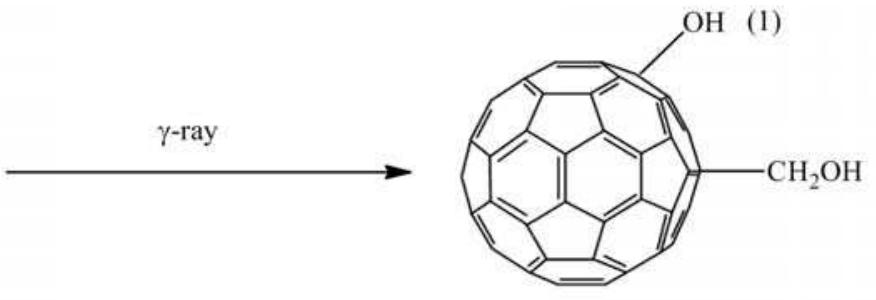

F-Fullerene $(\mathrm{C} 60(\mathrm{OH}))$

(1) $\mathrm{H}_{2} \mathrm{O} \stackrel{\gamma \text {-ray }}{\longrightarrow} \mathrm{E}_{\text {aq }}, \mathrm{H}^{+}, \mathrm{H} ;, \mathrm{OH}, \mathrm{H}_{2} \mathrm{O}_{2}, \mathrm{H}_{2}$

(2) $\mathrm{CH}_{3} \mathrm{OH}+\mathrm{OH}^{\cdot} \longrightarrow \mathrm{H}_{2} \mathrm{O}+\mathrm{CH}_{2} \mathrm{OH}^{\circ}$

Fig. 2. Radiolytic functionalization possible mechanism of Fullerene (C60) in $\mathrm{H}_{2} \mathrm{O} / \mathrm{MeOH}$ mixture solution.

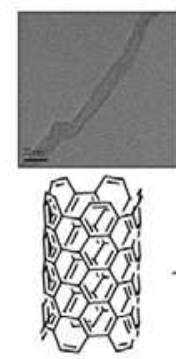

purified CNT
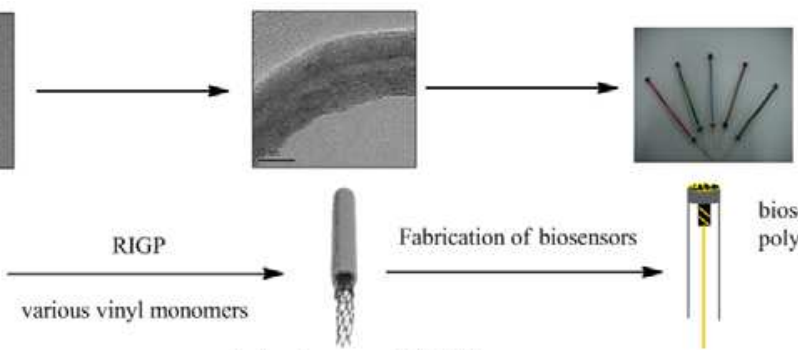

biosensor based on polymer-grafted CNT

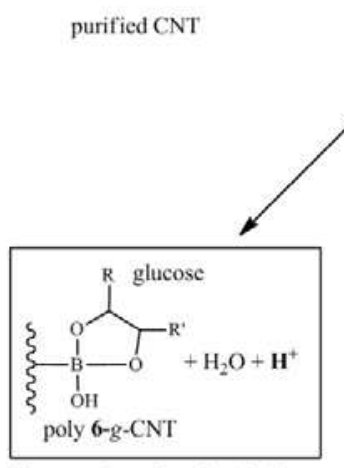

biosensor based on chemical rxn

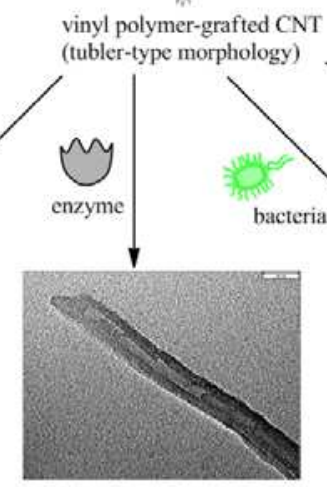

biosensor based on enzyme
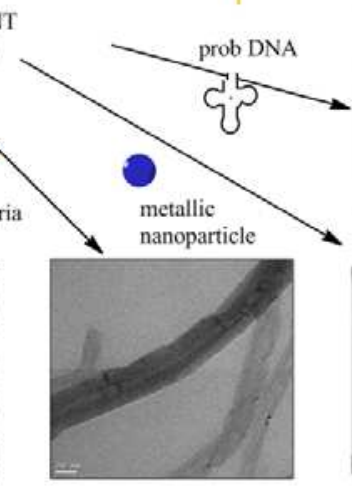

biosensor based on bacteria

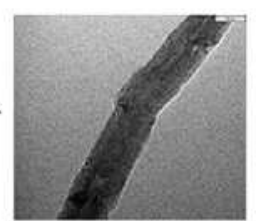

E-DNA sensor

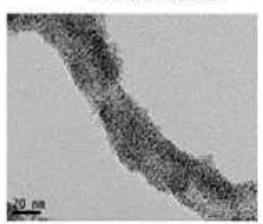

biosensor based on metallic catalyst

Fig. 3. Schemetic fabrication of biosensor based on vinyl polymer-grafted MWNT. 


\section{Enzyme-free biosensor based on chemical reaction}

Numerous methods based on enzyme immobilization for human cholesterol assays have been developed, including colorimetric, spectrometric and electrochemical methods (Crumbliss et al., 1993; Shumyantseva et al., 2004). The use of enzymes in the fabrication of sensors has advantages due to their rapid, selective, and sensitive nature. However, there exist some practical problems related to the use of enzymes in analytical devices due to their short lifetime and low reusability since they are easily affected by temperature, humidity, and $\mathrm{pH}$ (Gavalas \& Chaniotakis, 2000, 2001). To address these issues, non-enzymatic sensors based on the direct electrocatalytic oxidation of glucose are being investigated for their stability, simple fabrication, reproducibility, low cost, and freedom from oxygen limitation, unlike enzyme-based sensors (Lee et al., 2009). In this section, we discuss the preparation and characterization of enzyme-free biosensors based on boronic acid-modified and metallic nanoparticles-immobilized CNTs.

\subsection{Chemical reaction between boronic acid containing group modified carbon surface and target molecules}

Boronic acids $\left(-\mathrm{B}(\mathrm{OH})_{2}\right)$ can interact with cyanides (Badugu et al., 2004a) and fluorides (Cesare \& Lakowicz, 2002a), which have been explored for sensor development. Boronic acids binding with diols (J. Wang et al., 2005) have been mostly studied in developing fluorescent carbohydrate sensors. Boronic acids act as an electron withdrawing group in its neutral form, $-\mathrm{B}(\mathrm{OH})_{2}$, and as an electron donation group in its anionic form, $-\mathrm{B}(\mathrm{OH})_{3}$.
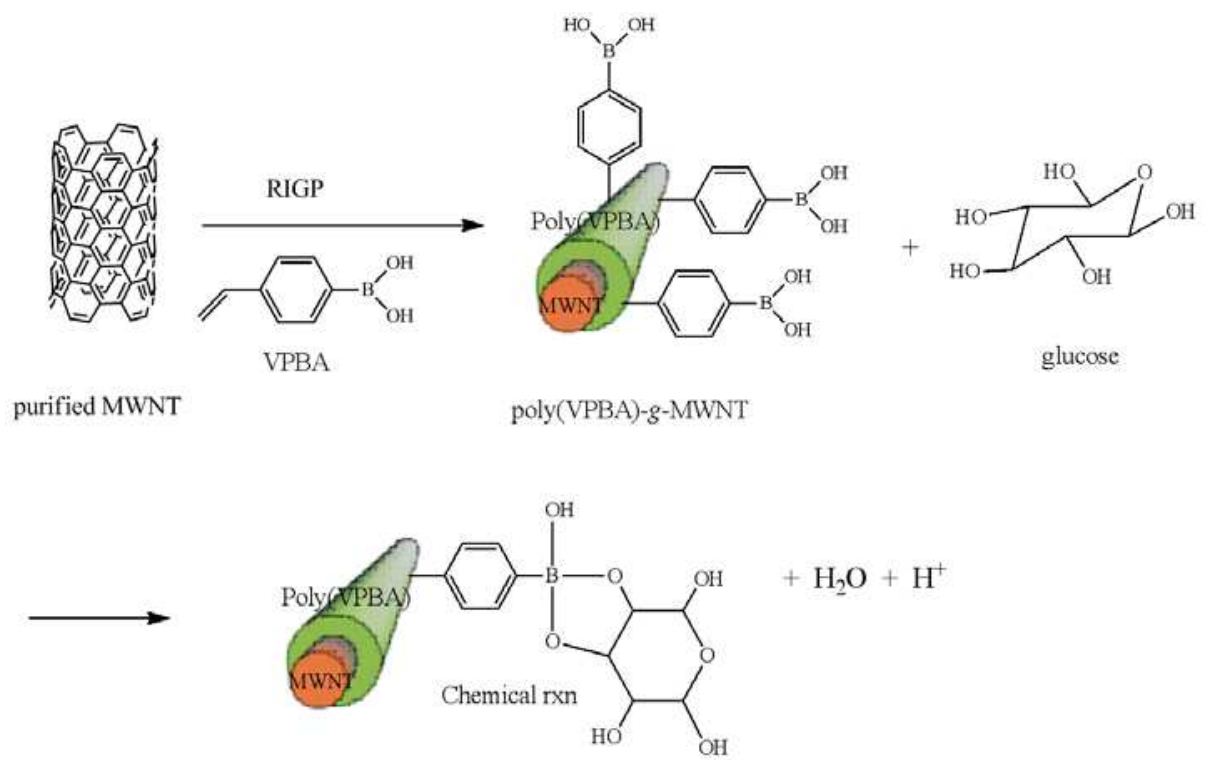

Fig. 4. Preparation of non-enzymatic biosensor based on chemical reaction by RIGP.

The feasibility of tear glucose sensing was tested using a daily disposable contact lens embedded with boronic acid-containing fluorophores which act as a potential alternative to current invasive glucose monitoring techniques (Badugu et al., 2004b). The boronic acid 
probes in the contact lens could continuously monitor the tear glucose levels in the range of 50-500 $\mu \mathrm{M}$. The boronic acid group showed higher affinity for D-fructose and smaller affinity for D-glucose (Cesare \& Lakowicz, 2002a). This means that the use of the boronic acid group for sensing sugars is strongly dependent on the molecular geometry and the aromatic species where boronic acid is present.

Poly(VBAc)-grafted MWNTs are of great interest for the preparation of enzyme-free sensors because of the boronic acid group they contain. 4-Vinylphenyl boronic acid (VPBA) was used to functionalize the surface of multi-walled carbon nanotubes (MWNTs) since it possesses both hydrophobic and hydrophilic properties (D. S. Yang et al., 2010). The vinyl group of the monomer attaches to the surface of MWNTs because of a hydrophobichydrophobic interaction, while the functional group of the monomer comes to the surface in an aqueous solution because of a hydrophilic-hydrophilic interaction. When irradiated, the radical polymerization of the monomer on the surface of MWNTs occurs to form grafted vinyl polymer PVBAc-g-MWNTs. Boronic acid in PVBAc-g-MWNTs couples with diols of glucose to form a boronic acid diester group, as shown in Figure 4 (D. S. Yang et al., 2010). The boronic acid content of PVBAc-g-MWNTs was $296 \mathrm{mg} / \mathrm{g}$, as determined by titration. The diols are linked covalently and the reaction is fast and completely reversible (Cesare \& Lakowicz, 2002b). The cyclic voltammograms of PVBAc-g-MWNTs in $0.1 \mathrm{M}$ phosphoric buffer solution displayed an excellent linear response to glucose concentration in the range $1.0-10 \mathrm{mM}$.

\subsection{Catalytic reaction of the target molecules on the surface of metallic nanoparticle- modified MWNT}

Recently, an enzyme-free hydrogen peroxide $\left(\mathrm{H}_{2} \mathrm{O}_{2}\right)$ biosensor was developed based on nano-conducting polymer composites (MWNT-PEDOT nanoparticles) (K. C. Lin et al., 2010). The use of enzyme-free $\mathrm{H}_{2} \mathrm{O}_{2}$ biosensors is important in chemical, food and environmental applications. More enzyme-free $\mathrm{H}_{2} \mathrm{O}_{2}$ biosensors have been developed based on modified carbon fiber microelectrodes (Y. Wang et al., 1998), vanadium-doped zirconias (Domenecha \& Alarcon, 2002) and $\mathrm{Fe}_{3} \mathrm{O}_{4}$ (M. S. Lin \& Leu, 2005).

Nanoscale materials of metal $(\mathrm{Ag}, \mathrm{Au}, \mathrm{Pd}, \mathrm{Pt}$, etc.), alloy $(\mathrm{Pt}-\mathrm{Ru})$, carbon and polymers are very attractive for a variety of applications including optical and electronic nanodevices, and chemical and biological nanosensors. Nanoparticles offer higher catalytic efficiency than bulk materials due to their large surface-to-volume ratio (Yu et al., 1999; S. J. Kim et al., 2008).

Initial research developing non-enzymatic sensors focused on the use of nanocrystalline metals, such as $\mathrm{Pt}$ and $\mathrm{Au}$, especially Pt-based amperometric electrodes (S. J. Park et al., 2003; Song et al., 2005). However, such Pt-based glucose sensors lacked sufficient selectivity and sensitivity due to chemisorbed intermediates and electroactive species. The desire for better and cheaper electrocatalysts has resulted in bimetallic systems being developed. Pt$\mathrm{Au}$ (Habrioux et al., 2007; H. Liu et al., 1992), Pt-Pb (Cui et al., 2007; Bai et al., 2008; J. Wang et al., 2008; Sun et al., 2001), and Pt-Ru (Xiao et al., 2009) have all displayed high electrocatalytic activity for glucose oxidation.

Effective fabrication of electrocatalysts also depends on the support material (Hsu et al., 2008). Catalyst dispersion and utilization have been shown to improve supporting Pt-Ru nanoparticles on high-surface area carbon materials, such as CNTs, carbon nanofibers, carbon nanocoils and carbon nanohorns (Steigerwalt et al., 2002; Hyeon et al., 2003; K. Park 
et al., 2004; R. Yang et al., 2005). A systematic study has shown that MWNTs are the best of the carbon based electrocatalyst supports (Reddy \& Ramaprabhu, 2007). In principle, MWNTs are seamless cylinders. However, they often have defects where the attachment of Pt-based alloy nanoparticles most likely occurs.

In a preliminary report, $\mathrm{Pt}-\mathrm{Ru}$ nanoparticles were deposited on the surfaces of various carbon supports, including Vulcan XC-71, Ketjen-300, Ketjen-600, single-walled carbon nanotubes (SWNTs), and MWNTs for use as fuel cell catalysts using $\gamma$-ray irradiation without anchoring agents (Choi et al., 2003a, 2003b; Oh et al., 2006; Hwang et al., 2008). The metal (Ag or Pd) and alloy (Pt-Ru) nanoparticles were also deposited on the surfaces of SWNTs (Oh et al., 2005, 2006a, 2006b, 2008) and porous carbon supports using Y-irradiation without anchoring agents (Seo et al., 2008). However, metallic alloy nanoparticles aggregated on the surfaces of the carbon supports due to their hydrophobic nature. This aggregation was overcome by modifying the surface of the carbon support to give it hydrophilic properties. This was done by in-situ polymerization of $\beta$-caprolactone, methacrylate and pyrrole using oxidizing agents as initiators (Bae et al., 2010). The polymerstabilized bimetallic (Pd-Ag) nanoparticles were prepared by $\gamma$-irradiation in organic solvents and used as catalysts for hydrogenation of cis,cis-1,3-cyclooctadiene (Choi et al., 2005). Pt- Ru nanoparticles were then deposited on the polymer-wrapped MWNT supports to produce a direct methanol fuel cell (DMFC) anode catalyst (Choi et al., 2010).

$\mathrm{Pt}-\mathrm{Ru}$ nanoparticles have also been deposited on functional polymer (FP)-grafted MWNTs by RIGP, to produce an anode catalyst for DMFCs (D. S. Yang et al., 2011). This method involved two steps: grafting the functional polymer onto the MWNTs by RIGP; and then depositing the Pt-Ru nanoparticles onto the MWNTs by radiation-induced reduction. Pt-M nanoparticles on FP-MWNT supports have also been prepared via a one-step process initiated by free radicals and hydrated electrons generated during $\gamma$-irradiation in an aqueous solution.

The catalytic efficiencies of the $\mathrm{Pd} / \mathrm{C}$ and $\mathrm{Pd}-\mathrm{M} / \mathrm{C}$ particles in various Suzuki-type and Heck-type reactions were examined (S. J. Kim et al., 2008; M. R. Kim \& Choi, 2009). In the Suzuki-type reactions, the catalytic efficiency (measured by the yield of the product) decreases in the order of $\mathrm{Pd}-\mathrm{Cu} / \mathrm{C}>\mathrm{Pd} / \mathrm{C}>\mathrm{Pd}-\mathrm{Ag} / \mathrm{C}>\mathrm{Pd}-\mathrm{Ni} / \mathrm{C}$. The reaction yield with $\mathrm{Pd}-\mathrm{Ni} / \mathrm{C}$ was much lower than those with other particles. Generally the carbon-supported $\mathrm{Pd}$ and Pd-M nanoparticles showed excellent capabilities as a catalyst for carbon-carbon coupling reaction such as Suzuki- and Heck-type reactions.

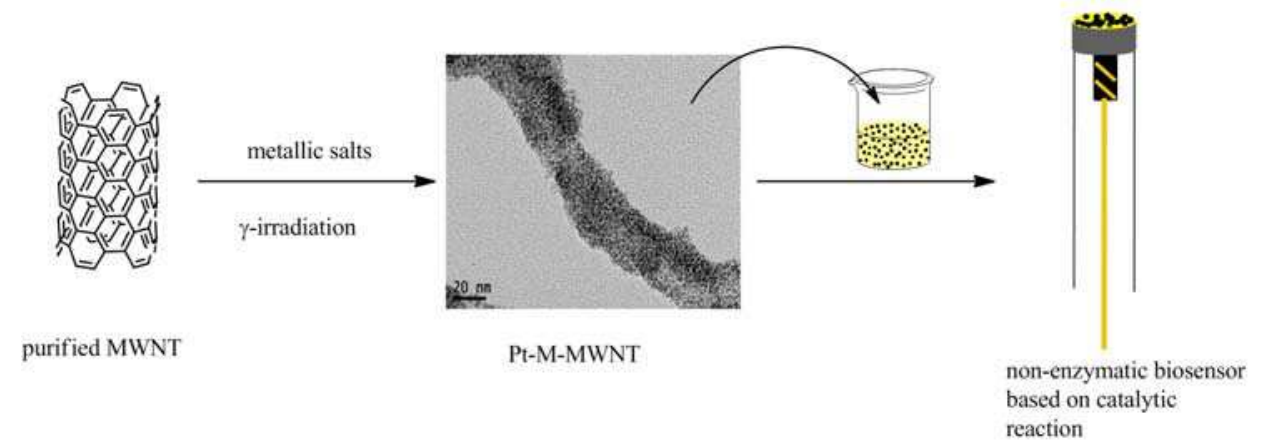

Fig. 5. Radiotic preparation of non-enzymatic biosensor based on catalytic oxidation. 
Non-enzymatic glucose sensors employing polyvinylpyrrolidone (PVP) modified-MWNTs with highly dispersed Pt-M (M = Ru and Sn) nanoparticles (Pt-M/PVP@MWNTs) were fabricated by radiolytic deposition (Kwon et al., 2011). The Pt-M nanoparticles were found to be well-dispersed and exhibit alloy properties on the MWNT supports. Electrochemical testing showed that these non-enzymatic sensors had larger currents $(\mathrm{mA})$ than that of a bare glassy carbon (GC) electrode and PVP modified-MWNTs. The prepared biosensor with $\mathrm{Pt}-\mathrm{Ru}$ nanoparticles for glucose has good sensitivity, linear range, and a lower detection limit in $\mathrm{NaOH}$ electrolyte. These non-enzymatic sensors can effectively avoid interference from ascorbic acid and uric acid in $\mathrm{NaOH}$ electrolyte.

\section{Enzymatic biosensors based on vinyl polymer grafted-MWNTs prepared by RIGP}

\subsection{Enzymatic biosensors}

The first enzyme electrode was an amperometric type of biosensor developed by Clark and Lyons (Clark \& Lyons, 1962). A soluble biomaterial glucose oxidase was held between membranes and the oxygen uptake was measured with an oxygen electrode. Since then, enzyme-based electrochemical biosensors have been widely used in medical and pharmaceutical applications, food safety and environmental monitoring, defense and security. Health care is the main area using biosensor applications today for monitoring blood glucose levels and diabetes. Also, potential applications exist for the reliable detection of urea in renal disease patients either at home or in the hospital. Industrial applications are used to improve manufacturing processes leading to better yield and product quality, such as monitoring the production of alcohol during the fermentation process. Furthermore, biosensors help to meet environmental legislation through monitoring of phenolic compounds contained in industrial waste water, much of which is toxic to the environment. Electrochemical biosensors incorporating enzymes with nanomaterials, which combine the recognition and catalytic properties of enzymes and the electronic properties of various nanomaterials, are the desired materials with synergistic properties originating from the components of the hybrid composites. Many enzymes have been employed to prepare various kinds of biosensors using carbon nanotubes (CNTs) (Chakraborty \& Raj, 2007; Male et al., 2007; Arvinte et al., 2008). Usually, enzymes are immobilized onto CNTs by physical adsorption (Guan et al., 2005) and covalent bonding (Patolsky et al., 2004; Y. J. Zhang et al., 2005). Various vinyl monomers, such as acrylic acid (AAc), methacrylic acid (MAc), glycidyl methacrylate (GMA), maleic anhydride (MAn), and 4-vinylphenylboronic acid (VPBAc), are used to functionalize CNTs prior to immobilizing enzymes onto CNTs. Figure 6 shows the vinyl monomers which possess both hydrophobic and hydrophilic properties. PolymerCNT nanocomposites have been obtained by $\gamma$-irradiation polymerization of various vinyl monomers. The obtained vinyl polymer-grafted CNTs are used as biosensor support materials to increase sensitivity and affinity for biomolecules.

Tyrosinase-immobilized biosensors were fabricated based on Poly(AAc)-g-MWNT and Poly(Man)-g-MWNT by RIGP of AAc and MAn on the surface of MWNTs, (\#1 and 4 in Fig. 6). The biosensor was then prepared on an indium tin oxide (ITO) glass electrode via a hand-casting of chitosan solution with tyrosinase-immobilized Poly(AAc)-g-MWNT (\#1 in Fig. 6) and Poly(Man)-g-MWNT (\#4 in Fig. 6) respectively. The sensing ranges of biosensors were $0.2-0.9 \mathrm{mM}$ and $0.1-0.5 \mathrm{mM}$ concentrations for phenol in phosphate buffer solution. Various parameters influencing biosensor performance have been optimized for $\mathrm{pH}$, 
temperature, and the response to various phenolic compounds. The biosensor was then tested on phenolic compounds contained in commercial red wines (K. I. Kim et al., 2010).

A tyrosinase-immobilized biosensor with hydroxyl group-functionalized MWNTs was also developed for phenol detection (J. H. Yang et al., 2009). The hydroxyl group-modified MWNTs include poly(GVPB)-g-MWNT and poly(HEMA) prepared by RIGP (\#5 and 6 in Fig. 6). The biosensor response was in the range of $0.6-7.0 \mathrm{mM}$ and $0.05-0.35 \mathrm{mM}$ for phenol in a phosphate buffer solution, respectively. The biosensor was then optimized for $\mathrm{pH}$, temperature, and other phenolic compounds in commercial red wines. As a result, the amount of phenolic compounds in commercial red wines are in the range of $68.5 \sim 655.0$ $\mathrm{mg} / \mathrm{L}$, which was calculated from a calibration curve of phenol on a biosensor based on poly(GVPB)-g-MWNTs.<smiles>C=CC(=O)O</smiles>

acrylic acid (1)

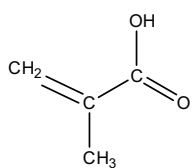

methacrylic acid (2)

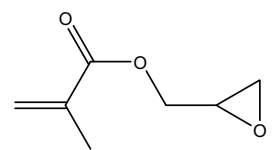

glycidyl methacrylate (3)

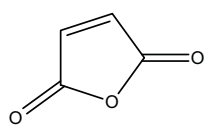

maleic anhydride (4)<smiles>C=C(C)C(=O)OCCO</smiles>

2-hydroxyethyl methacrylate (5)

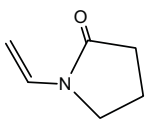

vinyl pyrrolidone (9)

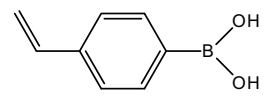

4-vinylphenylboronic acid (6)

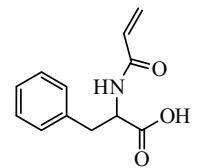

acryloyl-L-phenylalanine (10)

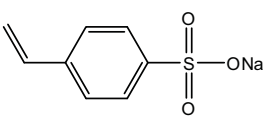

sodium styrenesulfonate (7)<smiles>C=CC(=O)NC(CC(C)C)C(=O)O</smiles>

acryloyl-L-leucine (11)

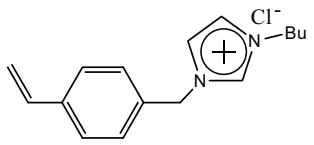

1-[(4-ethenylphenyl)methyl] -3-buthyl-imidazolium chloride $(\mathbf{8})$

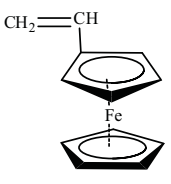

vinyl ferrocene (12)

Fig. 6. The used vinyl monomers in Choi lab. for radiation-induced grafting onto carbon nanotubes.

Direct electrochemistry of biological enzymes has been studied with ion liquids (ILs) in both theoretical and practical applications since ILs are considered to be suitable media for supporting a biocatalytic process with high polarity, non-coordination power, high selectivity, fast rates, and great enzyme stability (Compton \& Laszlo, 2002; Sweeny \& Peters, 2001). The cationic property of modified MWNT-based sensors was developed by RIGP of vinyl monomers with ionic properties, such as 1-butylimidazole bromide (\#8 in Fig. 6), 3(butyl imidazol)-2-(hydroxyl)propyl methyl methacrylate and 1-[(4-ethenylphenyl)methyl]3-buthyl-imidazolium chloride, in aqueous solution at room temperature (K. I. Kim et al., 2009; Ryu \& Choi, 2010a). Subsequently, the tyrosinase-immobilized biosensor was fabricated by hand-casting the ionic property-modified MWNTs, tyrosinase, and chitosan solution as a binder onto the ITO glass surface. The biosensors were used to determine phenolic compounds in red wines or caffeine in commercial coffee. As a result, the amount of 
phenolics in commercial red wines has been determined to be in the range of 383.5-3,087 $\mathrm{mg} / \mathrm{L}$ in a phosphate buffer solution (K. I. Kim et al., 2009), and the amount of caffeine in commercial coffee was in the range of $144.8 \sim 1765 \mathrm{mg} / \mathrm{L}$ in a phosphate buffer solution (Ryu \& Choi, 2010a).

In addition, colloidal gold nanoparticles (Au-NPs) have been widely used as a model system because of their ease of synthesis and surface modification (Feng et al., 2007), good biocompatibility (Qu et al., 2006), as well as their ability to act as tiny conduction centers which facilitate electron transfer (Jia et al., 2002). Fabrication of a gucose oxidase (GODox) immobilized biosensor has been attempted by two methods (Piao et al., 2010). In one of the methods, gold nanoparticles (Au-NPs) prepared by $\gamma$-irradiation were loaded into the poly(MAn)-g-MWNT electrode via physical entrapment. In the other method, the Au-NPs were prepared by electrochemical reduction of $\mathrm{Au}$ ions on the surface of the poly(MAn)-gMWNT electrode and then GODox was immobilized into the Au-NPs. The GODox immobilized biosensors were tested for electrocatalytic activity to sense glucose. The sensing range was from $30 \mu \mathrm{M}$ to $100 \mu \mathrm{M}$ for the glucose concentration, and the detection limit was $15 \mu \mathrm{M}$. Interference of ascorbic acid and uric acid were below 7.6\%. The physically $\mathrm{Au}$ deposited poly(MAn)-g-MWNT paste electrodes appear to be good sensors in detecting glucose.

Hydroxyl group was introduced onto the surface of fullerene by RIGP of VPBA in a methanol/1,2-dichlorobenzene mixture solution. The obtained functionalized-fullerene, Ffullerene, was then used as a sensor support material. The enzyme electrode was prepared on the ITO electrode via hand-casting of the chitosan solution based on F-fullerene and tyrosinase. The sensing range of the biosensor was $0.1 \sim 0.6 \mathrm{mM}$ for phenol in a phosphate buffer solution. Furthermore, the prepared biosensor was used to determine concentration of phenolics in commercial red wines (Chung et al, 2011).

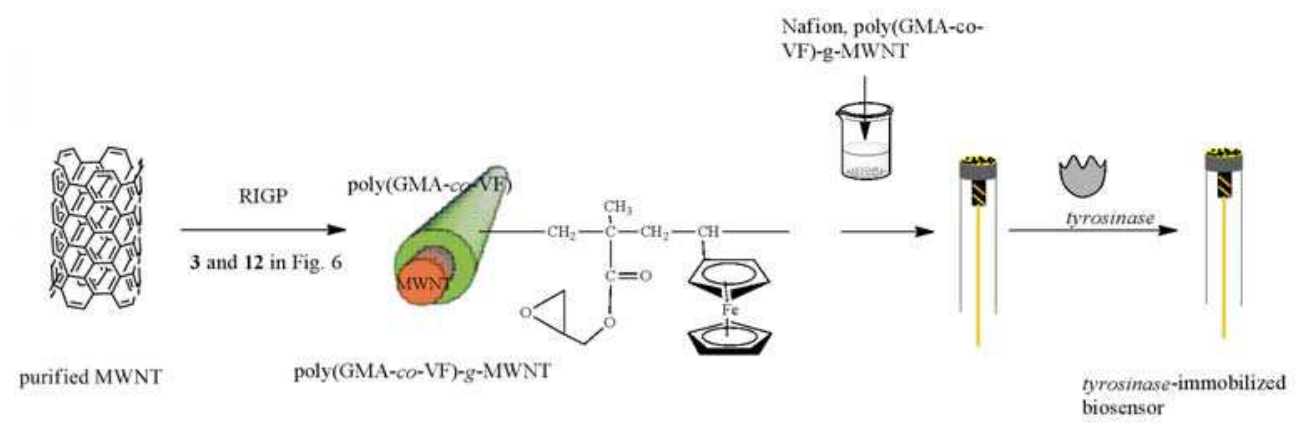

Fig. 7. Preparation of enzymatic biosensor based on poly(GMA-co-VF)-g-MWNT prepared by RIGP.

Ferrocene derivatives are widely used as electron transfer mediators for amperometric glucose biosensors since ferrocene meets the criteria of a good mediator, such as inert behavior with oxygen, stable in both redox forms, independent of $\mathrm{pH}$, shows reversible electron transfer kinetics, and reacts rapidly with enzymes (Eggins, 1996). A polymeric mediator is necessary since polymers allow the incorporation of reagents to achieve reagentless sensing devices. Some examples of redox copolymers trialing the covalent attachment of ferrocene include poly(vinylferrocene-co-hydroxyethyl methacrylate), 
poly(N-acryloylpyrrolidine-co-vinylferrocene) and ferrocene-containing polythiophene derivative (T. Saito \& Watanabe, 1998; Koide \& Yokoyama, 1999).

The electrochemical phenol biosensor was fabricated by immobilizing tyrosinase on poly(glycidyl methacrylate-co-vinylferrocene)/MWNT [poly(GMA-co-VFc)/MWNT] film, as shown in Fig. 7. A polymeric electron transfer mediator, containing copolymers of glycidyl methacrylate (GMA) and vinylferrocene ( $\mathrm{VFc}$ ) with different molar ratios, was prepared by RIGP. The prepared poly(GMA-co-VFc)/MWNT was confirmed via Fourier transform infrared spectrometer (FT-IR), thermogravimetric analysis (TGA), transmission electron microscopy (TEM) and X-ray photoelectron spectra (XPS). Also, the sensing efficiency of the fabricated electrochemical phenol biosensor was evaluated by cyclic voltametric (CV) (Lee \& Choi, 2010).

\subsection{ECL biosensor}

Electrogenerated chemiluminescence (ECL) is a light emission produced from a high energy electron transfer (redox) reaction between electrogenerated species, which is usually accompanied by the regeneration of emitting species. In ECL, light emission is controlled by turning on/off the electrode potential. ECL has been receiving great attention as an important and valuable detection method in analytical chemistry. Application of ECL is widely found in chemical sensing (Knight, 1999), imaging (Wightman et al., 1998), and optical studies (Fan et al., 1998). Moreover, it is also used in chromatography (Noffsinger \& Danielson, 1987) and capillary electrophoresis (Arora et al., 2001). Among the various ECL systems, $\mathrm{Ru}(\mathrm{bpy}) 3^{2+}$ is the most widely used complex due to its excellent intrinsic characteristics and capability to produce ECL with a wide range of analysis, such as oxalate, amines, and amino acid.

Chemiluminescence Sensor was fabricated based on conducting polymer@SiO $/ \mathrm{Nafion}$ composite film (Jung et al., 2010). The Tris(2,2'-bipyridyl)ruthenium (II) (Ru(bpy) $3^{2+}$ ) ECL sensor was fabricated by immobilization of $\mathrm{Ru}(\mathrm{bpy}) 3^{2+}$ complex on the functionalized MWNT-Nafion composite film coated glass carbon (GC) electrode. The functionalized MWNT was prepared by coating polythiophene (PTh), polyaniline (PANI), and poly(3thiopheneacetic acid) $[\mathrm{P}(3-\mathrm{TAA})]$ on the surface of the carboxylic acid-modified MWNTs. The sensitivity and reproducibility of the prepared ECL sensor to tripropylamine (TPA) was evaluated. As a result, the carboxylic acid-modified MWNT composite electrode showed higher sensitivity and better reproducibility than that of other functionalized MWNT composite electrodes (S. H. Kim et al., 2008).

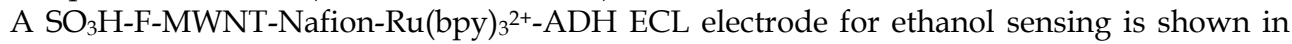
Fig. 8. The ECL sensor was fabricated by immobilization of $\mathrm{Ru}(\mathrm{bpy})_{3}{ }^{2+}$ on the $\mathrm{SO}_{3} \mathrm{H}-$ functionalized MWNT ( $\mathrm{SO}_{3} \mathrm{H}-\mathrm{F}-\mathrm{MWNT}$ )-Nafion composite film coated on a GC electrode. Finally, ADH was immobilized on the electrode in a phosphate buffer solution at $4{ }^{\circ} \mathrm{C}$. The $\mathrm{SO}_{3} \mathrm{H}-\mathrm{F}-\mathrm{MWNT}$ ECL biosensor showed higher sensing efficiency for ethanol than that of the ECL biosensor prepared by purified MWNT. Experimental parameters affecting ethanol detection were also examined in terms of $\mathrm{pH}$, and the content of $\mathrm{SO}_{3} \mathrm{H}-\mathrm{F}-\mathrm{MWNT}$ in Nafion. Little interference of other compounds for assay of the ethanol was observed. Results suggest that the ECL biosensor could be applied for ethanol detection in real samples (Ryu \& Choi, 2010b).

A COOH-F-MWNT-Nafion-Ru(bpy) ${ }_{3}{ }^{2+}-\mathrm{Au}-\mathrm{ADH}$ ECL electrode using $\mathrm{COOH}$-functionalized MWNTs (COOH-F-MWNT) and $\mathrm{Au}$ nanoparticles synthesized by $\mathrm{\gamma}$-irradiation was fabricated for ethanol sensing (Piao et al., 2009). Here, Au atoms were produced in solution 
by radiation-induced reduction of $\mathrm{Au}$ ion-precursors without chemical reducing agents. The species arising from the radiolysis of water, solvated electrons, $\mathrm{e}_{\mathrm{aq}}{ }^{-}$, and $\mathrm{H}^{-}$atoms are the strongest reducing agents. They easily reduce $\mathrm{Au}$ ions to produce $\mathrm{Au}$ nanoparticles. A higher sensing efficiency for ethanol for the ECL biosensor prepared by Poly(AAc)g-MWNT (\#1 in Fig. 6) was measured compared to that of the ECL biosensor prepared by Poly(Mac)g-MWNT (\#2 in Fig. 6), and purified MWNT. Experimental parameters affecting ethanol detection were also examined in terms of $\mathrm{pH}$ and the content of Poly(AAc)-g-MWNT in Nafion. The sensors can effectively avoid interference from the oxidation of citric acid, ascorbic acid, acetic acid and oxalic acid. The experimental results show that the ECL biosensor could be applied for ethanol detection in real samples (Piao et al., 2009).

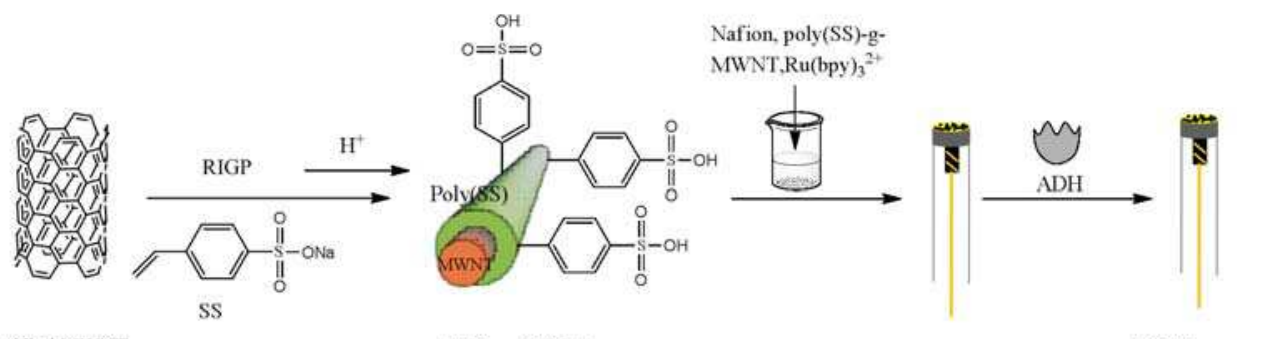

purified MWNT

poly(SS)-g-MWNT

ECL biosensor

Fig. 8. Preparation of ECL biosensor based on poly(SS)-g-MWNT prepared by RIGP.

\section{Bacteria biosensors based on polymer grafted MWNTs prepared by RIGP}

Various bio-elements, including enzymes, antibodies, microorganism, organelles, tissues, and cells have been used in the fabrication of biosensors (Lei et al., 2006). Enzymes are the most widely used bio-element due to their unique specificity and sensitivity (D'Souza, 2001). However, the use of enzymes is often hampered by costly and time-consuming procedures in purification. Also, the enzyme activity could be decreased in in vitro operating environments (Byfield \& Abuknesha, 1994). Microbes, such as algae, bacteria, and yeast can be alternatively used in the fabrication of biosensors since they can be massively produced by cell culturing. In addition, microbial cells are relatively easier to be manipulated and have better viability and stability in vitro compared to the cells from higher organisms such as plants, animals, and human beings (Byfield \& Abuknesha, 1994).

Bacterial sensors using Pseudomonas fluorescens (Pseudomonas putida DSM 6521) and P. putida DSM 50026 cells entrapped with chitosan matrix onto the surface of graphite electrodes have been prepared (Odaci et al., 2008). The measurements were based on the respiratory activity of the cells. The sensor showed good linearity and repeatability with high operational stability. Also prepared were CNT-modified chitosan membranes to test the effect of nanoparticles on the biosensor performance. The results showed that combining the properties of carbon nanotubes and the versatility and biocompatibility of chitosan created chitosan surface coated carbon nanotubes.

As discussed earlier, nanomaterials have been used to improve the efficiency of electron transfer between the redox center of enzymes and electrodes (Li et al., 2006; Zhang \& Fang, 2010; Guo et al., 2008). Owing to their unique properties, quantum dots (QDs) have 
generated considerable interest as electron transport nanomaterials for biodetection. The direct electron transfer of glucose oxidase (GOD) adsorbed on a CdS QDs modified pyrolytic graphite electrode has been reported, where the enzyme demonstrated significantly enhanced electron-transfer reactivity (Huang et al., 2007). The CdS QDs-coated electrode was displayed as a pair of well-defined redox peaks of GOD.

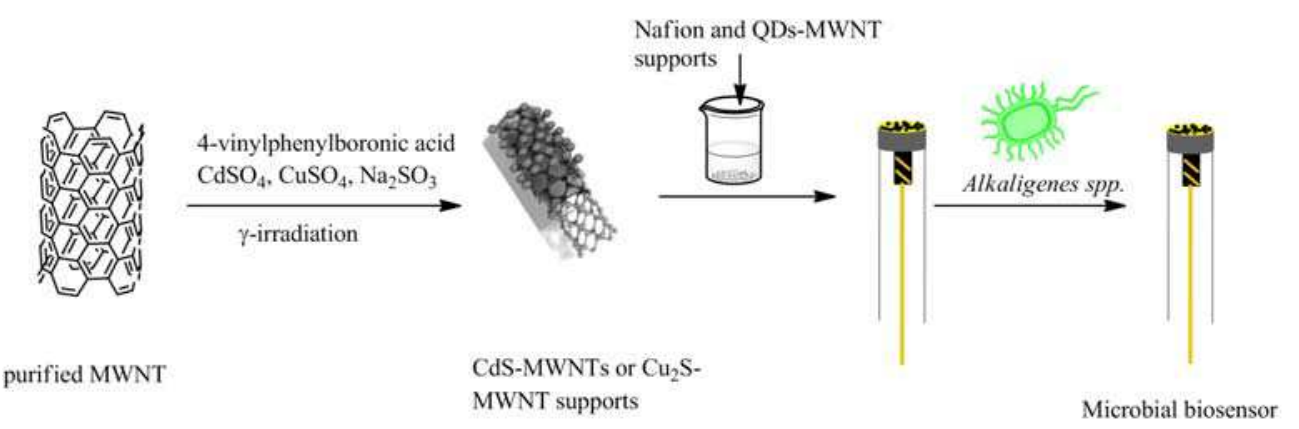

Fig. 9. Preparation of microbial biosensor based on QD-MWNT prepared by radiation reaction.

The Acaligense sp.-immobilized biosensor was fabricated based on QD-MWNT composites as an electron transfer mediate and a microbe immobilization support for sensing phenolic compounds in commercial red wines, as shown in Fig. 9 (S. K. Kim et al., 2011). First, the quantum dot-modified MWNT composite (QD-MWNTs) was prepared in an aqueous solution at room temperature. The successful preparation of the QD-MWNT composite was confirmed through XPS, TEM, and elemental analysis. Second, the microbial biosensor was fabricated by immobilization of Acaligense sp. on the surface of the GC electrode, which was prepared by hand-casting with the mixture of obtained composite and Nafion solution. The sensing ranges of the microbial biosensor based on CdS-MWNT and $\mathrm{Cu}_{2} \mathrm{~S}-\mathrm{MWNT}$ supports were $0.5-5.0 \mathrm{mM}$ and $0.7-10 \mathrm{mM}$ for phenol in phosphate buffer solution, respectively. Total concentration of phenolic compounds contained in commercial red wines was also determined using the prepared microbial immobilized biosensor (S. K. Kim et al., 2011). RIGP of the poly(GMA) onto MWNT surfaces in an aqueous solution at room temperature was performed to introduce an epoxy group (Shin et al, 2011). The epoxy group can be easily converted to alcohols, amines, phosphonic acid, and sulfonic acid. Subsequently, triethylene diamine (TEDA) was introduced onto the epoxy group of the grafted poly(GMA) to prepare MWNT supports with an amine group. Finally, the electrochemical microbial biosensor (EMB) was fabricated after immobilization of a microbe (Alkaligenes spp.) on the modified electrode. The EMB was evaluated for its sensing efficiency for phenol in a phosphate buffer solution. The total concentration of phenolic compounds in commercial red wines was determined using the EMB.

\section{E-DNA biosensor based on polymer grafted MWNT prepared by RIGP}

Currently, direct detection of nucleic acids is an area of tremendous interest, as it plays a major role in forensics (Jelly et al., 2008), pharmaceutical applications (Kranaster \& Marx, 2007), medical diagnosis (Marras et al., 2006), food and agricultural analysis (Timko et al., 
2008), and environmental control (X. C. Shen et al., 2008). Electrochemical transducers offer many potential advantages that include sensitivity, accurate specificity, simplicity and lowcost, in converting nucleic acid hybridization events into useful analytical signals (Millan et al., 1994; Hashimoto et al., 1994; S. F. Wang et al., 2005). Electrochemical DNA (E-DNA) biosensors have been popularly developed for DNA sequence analysis with immobilization of single-stranded DNA (ssDNA) probes on various electrode surfaces (Niu et al., 2009).

Fabrication of E-DNA biosensors has been reported by the physical immobilization of probe DNA, 5' $\mathrm{NH}_{2}$-GGA GCT GCT GGC ATT ATT GAA-3', on ionic-liquid (IL) modified MWNTs with ITO electrodes to detect Salmonella typhi (S. typhi), as shown in Fig. 10 (Chung et al., 2009). IL-MWNTs were prepared by the introduction of 1-butylimidazole bromide onto an epoxy group on poly(GMA)-grafted MWNTs, which were synthesized by RIGP of GMA onto MWNTs in aqueous solution. Subsequently, IL-MWNTs were coated onto the ITO electrode surface, and then the physical immobilization of the probe DNA performed in solution at room temperature for $1 \mathrm{~h}$. The IL-MWNTs were characterized by elemental analysis, XPS, and TGA. The electron transfer resistance $\left(\mathrm{R}_{\mathrm{et}}\right)$ of the E-DNA biosensor was evaluated after hybridization of the probe DNA and target DNA using electrochemical impedance spectroscopy (EIS). The $\mathrm{R}_{\mathrm{et}}$ increased after the hybridization of probe DNA and target DNA. The target DNAs used were: (1) Complementary DNA, 5'-TTC AAT AAT GCC AGC AGC TCC-3', (2) Single-base mismatch DNA, 5'-TTC AAT AAT GGC AGC AGC TCC3 ' and (3) Three-base mismatch DNA, 5'-TTC ATT AAT GGC AGC ACG TCC-3' (Chung et al. 2009).

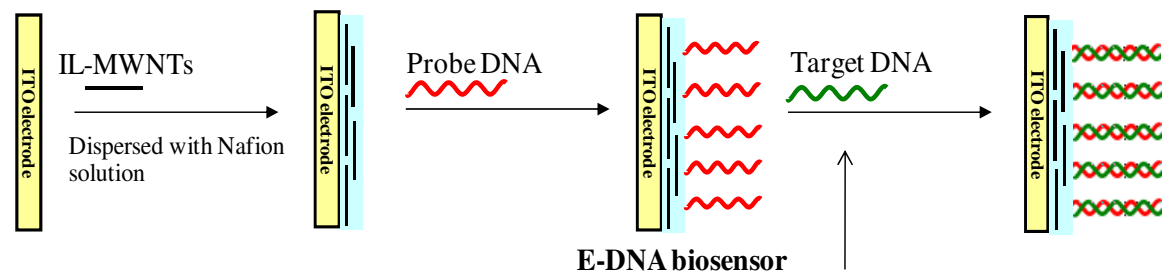
Probe DNA(ssDNA)
5'-GGA GCT GCT GGC ATT ATT GAA-3'
Complementary DNA (cDNA)5'-TTC AAT AAT GCC AGC AGC TCC-3'
Single-base mismatch DNA 5'-TTC AAT AAT GGC AGC AGC TCC-3'
Three-base mismatchDNA 5'-TTC ATT AAT GGC AGC ACG TCC-3'

Fig. 10. Preparation of E-DNA biosensor based on IL-MWNTs prepared by RIGP.

\section{Conclusion}

This chapter has discussed fabrication of biosensors using vinyl polymer-grafted carbon nanotubes prepared by RIGP. To fabricate a biosensor, biomolecules should be immobilized on transducers or support matrices either by chemical methods or by physical methods. Nanostructured materials have been applied in biosensing due to their good biocompatibility, enhanced electron transfer property, and high surface area. Immobilization of bio-elements on nanostructured electrodes could potentially improve the sensitivity of biosensors The small size and electronic properties of CNTs make them ideal for use in electrochemical biosensors and nanoscale electronic devices. However, the insolubility of CNTs in most 
solvents is a major barrier for developing such CNT-based biosensing devices. Therefore, surface modification is necessary for CNT materials to be biocompatible and to improve solubility in common solvents and selective binding capability to biotargets. Various vinyl monomers have been used to functionalize CNTs since they possess both hydrophobic and hydrophilic properties. The vinyl group of the monomer comes to the surface of CNTs because of a hydrophobic-hydrophobic interaction, while the functional group of monomer comes to the surface in an aqueous solution because of a hydrophilic-hydrophilic interaction.

When irradiated by $\gamma$-rays, the radical polymerization of the monomer on the surface of CNT occurs. RIGP is a useful method for the introduction of functional groups into polymer matrices using specially selected vinyl monomers. Two active species such as a free radical and a hydrated electron generated during $\gamma$-irradiation are used in preparing polymer nanocomposites. Various polymer-CNT nanocomposites using RIGP of the desired vinyl monomers can be prepared in a one-step process at room temperature and ambient pressure. The obtained vinyl polymer-grafted CNTs are used as biosensor supporting materials to increase sensitivity and affinity for biomolecules.

Catalyst dispersion and utilization have been shown to improve supporting $\mathrm{Pt}-\mathrm{Ru}$ nanoparticles on high-surface area carbon materials. The metal (Ag or Pd) and alloy (Pt-Ru) nanoparticles have been deposited on the polymer-wrapped MWNT supports using $\gamma^{-}$ irradiation without anchoring agents. Non-enzymatic glucose sensors employing PVP modified-MWNTs with highly dispersed $\mathrm{Pt}-\mathrm{M}(\mathrm{M}=\mathrm{Ru}$ and $\mathrm{Sn})$ nanoparticles were fabricated by radiolytic deposition. The biosensor with $\mathrm{Pt}-\mathrm{Ru}$ nanoparticles for glucose shwed good sensitivity, linear range, and a lower detection limit in $\mathrm{NaOH}$ electrolyte.

The obtained vinyl polymer-grafted CNTs have been successfully used as biosensor supporting materials for various types biosensors, including enzyme-free biosensors, enzymatic biosensors, bacterial biosensors, and E-DNA biosensors. Poly(VPBAc)-grafted MWNTs were prepared and used in enzyme-free glucose sensors for the detection of glucose without enzymes. The electrode displayed an excellent linear response to glucose concentration in the range 1.0-10 mM. The tyrosinase-immobilized biosensor was fabricated by a hand-casting of the modified MWNTs, tyrosinase, and chitosan solution as a binder onto ITO glass surface. The sensing ranges of the tyrosinase-biosensor for phenol in phosphate buffer solution was in the range of $0.005 \sim 0.2 \mathrm{mM}$. The biosensors were used to determine phenolic compounds in red wines or caffeine in commercial coffee. The Acaligense sp.immobilized biosensor was also fabricated based on QD-MWNTs composites as an electron transfer mediator and a microbe immobilization support for sensing phenolic compounds in commercial red wines. E-DNA biosensor has been fabricated by physical immobilization of probe DNA on IL-MWNTs modified glassy carbon (GC) electrode in order to detect Salmonella typhi (S. typhi).

\section{References}

Arora, A., Eijkel, J. C. T., Morf, W. E. \& Manz, A. (2001). A Wireless Electrochemiluminescence Detector Applied to Direct and Indirect Detection for Electrophoresis on a Microfabricated Glass Device. Anal. Chem., Vol. 73, No. 14, (June 2001), pp. 3282-3288, ISSN 0003-2700 
Arvinte, A., Sesay, A. M., Virtanen, V. \& Bala, C. (2008). Evaluation of Meldola Blue-Carbon Nanotube-Sol-Gel Composite for Electrochemical NADH Sensors and Their Application for Lactate Dehydrogenase-Based Biosensors. Electroanalysis, Vol. 20, No. 21, (November 2008), pp. 2355-2362, ISSN 1521-4109

Badugu, R., Lakowicz, J. R. \& Geddes, C. D. (2004a). Excitation and emission wavelength ratiometric cyanide-sensitive probes for physiological sensing. Anal. Biochem., Vol. 327, No. 1, (April 2004), pp. 82-90, ISSN 0003-2697

Badugu, R., Lakowicz, J. R. \& Geddes, C. D. (2004b). Noninvasive continuous monitoring of physiological glucose using a monosaccharide-sensing contact lens. Anal. Chem., Vol. 76, No. 3, (February 2004), pp. 610-618, ISSN 0003-2700

Bae, H. B., Ryu, J. H., Byun, B. S., Jung, S. H. \& Choi, S. H. (2010). Facile synthesis of a few novel Pt-Ru@PPy-MWNT electrocatalysts for direct methanol fuel cells. Current Applied Physics, Vol. 10, No. 2, (March 2010) pp. S44-S50, ISSN 1567-1739

Bahr, J. L., Mickelson, A. T., Bronikowski, M. J., Smalley, R. E. \& Tour, J. M. (2001). Dissolution of small diameter single-wall carbon nanotubes in organic solvents. Chem. Commun., Vol. 2001, No. 2, (January 2001), pp. 193-194, ISSN 1359-7345

Bai, Y., Sun, Y. \& Sun, C. (2008). Pt-Pb nanowire array electrode for enzyme-free glucose detection. Biosens. Bioelectron., Vol. 24, No. 4, (December 2008), pp. 579-585, ISSN 0956-5663

Byfield, M.P. \& Abuknesha, R.A. (1994). Biochemical aspects of biosensors. Biosens. Bioelectron., Vol. 9, No. 4-5, (May 1994), pp. 373-399, ISSN 0956-5663

Cesare, N. D. \& Lakowicz, J. R. (2002a). New sensitive and selective fluorescent probes for fluoride using boronic acid. Anal. Biochem., Vol. 301, No. 1, (February 2002), pp. 111-116, ISSN 0003-2697

Cesare, N. D. \& Lakowicz, J. R. (2002b). Charge transfer fluorescent probes using boronic acids for monosaccharide signaling. J. Biomed. Opt., Vol. 7, No. 4, (October 2002), pp. 538-545, ISSN 1083-3668

Chakraborty, S. \& Raj, C. R. (2007). Mediated electrocatalytic oxidation of bioanalytes and biosensing of glutamate using functionalized multiwall carbon nanotubesbiopolymer nanocomposite. J. Electroanal. Chem., Vol. 609, No. 2, (November 2007), pp. 155-162, ISSN 0022-0728

Choi, S. H., Nho, Y. C. \& Kim, G. T. (1999). Adsorption of $\mathrm{Pb}^{2+}$ and $\mathrm{Pd}^{2+}$ on Polyethylene Membrane with Amino Group Modified by Radiation-Induced Graft Copolymerization. J. Appl. Polym. Sci., Vol. 71, No. 4, (January 1999), pp. 643-650, ISSN 1097-4628

Choi, S. H. \& Nho, Y. C. (1999a). Adsorption of $\mathrm{Co}^{2+}$ and $\mathrm{Cs}^{1+}$ by Polyethylene Membrane with Iminodiacetic Acid and Sulfonic Acid Modified by Radiation-Induced Graft Copolymerization. J. Appl. Polym. Sci., Vol. 71, No. 6, (February 1999), pp. 999-1006, ISSN 1097-4628

Choi, S. H. \& Nho, Y. C. (1999b). Adsorption of $\mathrm{Co}^{2+}$ by Styrene-g-polyethylene Membrane Bearing Sulfonic Acid Group Modified by Radiation-Induced Graft Copolymerization. J. Appl. Polym. Sci., Vol. 71, No. 13, (March 1999), pp. 2227-2235, ISSN 1097-4628

Choi, S. H., Park, S. Y. \& Nho, Y. C. (2000a). Electrochemical properties of polyethylene membrane modified with carboxylic acid group. Radiat. Phys. Chem., Vol. 57, No. 2, (February 2000), pp. 179-186, ISSN 0969-806X 
Choi, S. H., Lee, K. P., Lee, J. G. \& Nho, Y. C. (2000b). Graft Copolymer-metal Complexes Obtained by Radiation Grafting on Polyethylene Film. J. Appl. Polym. Sci., Vol. 77, No. 3, (July 2000), pp. 500-508, ISSN 1097-4628

Choi, S. H., Kang, H. J., Ryu, E. N. \& Lee, K. P. (2001). Electrochemical Properties of Polyolefin Nonwoven Fabric Modified with Carboxylic Acid Group for Battery Separator. Radiat. Phys. Chem., Vol. 60, No. 4-5, (March 2001), pp. 495-502, ISSN 0969-806X

Choi, S. H., Lee, S. H., Hwang, Y. M., Lee, K. P. \& Kang, H. D. (2003a). Interaction between the surface of the silver nanoparticles prepared by $\gamma$-irradiation and organic molecules containing thiol group. Radiat. Phys. Chem., Vol. 67, No. 3-4, (June 2003), pp. 517-521, ISSN 0969-806X

Choi, S. H., Lee, K. P. \& Park, S. B. (2003b). Preparation and characterization of poly(ester)silver and nylon-silver nanocomposites. Proceedings of the $3^{\text {rd }}$ International Materials Symposium, ISBN 9780444514349, Jeju, Korea, July 2002

Choi, S. H., Lee, S., Kim, S. J., Sohn, S. H., Kang, H. D., Zhang, Y. P., Lee, K. P. \& Chun, J. H. (2005). Preparation of Polymer-Stabilized Palladium-Silver Bimetallic Nanoparticles by $\gamma$-Irradiation and Their Catalytic Properties for Hydrogenation of cis,cis-1,3Cyclooctadiene. Catalysis Letters, Vol. 105, No. 1-2, (November 2005), pp. 59-65, ISSN 1011-372X

Choi, S. H., Gopalan, A. I., Ryu, J. H. \& Lee, K. P. (2010). Hollow Spherical Nanocapsules of Poly(pyrrole) as a promising support for PtRu nanoparticles - A New Strategy for catalyst preparation to Direct Methanol Fuel Cells. Mater. Chem. Phys., Vol. 120, No. 1, (March 2010), pp. 18-22, ISSN 0254-0584

Chung, D. J., Kwon, S. Y. \& Choi, S. H. (2009). Fabrication of E-DNA sensor based on Au nanoparticle and ionic liquid-modified MWNT, Proceedings of the IUPAC 5th International Symposium, shanghai, China, October 2009

Chung, D. J., Kim, K. I., Seong, M. K. \& Choi, S. H. (2011). Radiolytic synthesis of -OH group functionalized fullerene structures and their biosensor application, J. Appl. Polym. Sci., accepted on now (2011-01-19). ISSN 1097-4628

Clark, L. \& Lyons, C. (1962). Electrode systems for continuous monitoring in cardiovascular surgery. Ann. N.Y. Acad. Sci., Vol. 102, (October 1962), pp. 29-45, ISSN 1749-6632

Compton, D. L. \& Laszlo, J. A. (2002). Direct electrochemical reduction of hemin in imidazolium-based ionic liquids. J. Electroanal. Chem., Vol. 520, No. 1-2, (February 2002), pp. 71-78, ISSN 1572-6657

Crumbliss, A. L., Stonehuerner, J. G., Henkens, R. W., Zhao, J. \& O'Daly, J. P. (1993). A carrageenan hydrogel stabilized colloidal gold multi-enzyme biosensor electrode utilizing immobilized horseradish peroxidase and cholesterol oxidase/cholesterol esterase to detect cholesterol in serum and whole blood. Biosens. Bioelectron., Vol. 8, No. 6, (June 1993), pp. 331-337, ISSN 0956-5663

Cui, H. F., Ye, J. S., Zhang, W. D., Li, C. M., Luong, J. H. T. \& Sheu, F. S. (2007). Selective and sensitive electrochemical detection of glucose in neutral solution using platinumlead alloy nanoparticle/carbon nanotube nanocomposites. Anal. Chim. Acta, Vol. 594, No. 2, (July 2007), pp. 175-183, ISSN 0003-2670

D'Souza, S. F. (2001). Microbial biosensors. Biosens. Bioelectron., Vol. 16, No. 6, (August 2001), pp. 337-353, ISSN 0956-5663 
Domenecha, A. \& Alarcon, J. (2002). Determination of hydrogen peroxide using glassy carbon and graphite/polyester composite electrodes modified by vanadium-doped zirconias. Anal. Chim. Acta, Vol. 452, No. 1, (January 2002), pp. 11-22, ISSN 00032670

Dzyadevych, S. V., Arkhypova, V. N., Soldatkin, A. P., El'skaya, A. V., Martelet, C. \& Jaffrezic-Renault, N. (2008). Amperometric enzyme biosensors: Past, present and future. Irbm, Vol. 29, No. 2-3, (April-May 2008), pp. 171-180, ISSN 1959-0318

Eggins, B. (1996). Biosensors: An Introduction, Wiley \& Teubner, London

Eitan, A., Jiang, K., Dukes, D., Andrews, R. \& Schadler, L. S. (2003). Surface Modification of Multiwalled Carbon Nanotubes: Toward the Tailoring of the Interface in Polymer Composites. Chem. Mater., Vol. 15, No. 16, (August 2003), pp. 3198-3201, ISSN 08974756

Fan, F.-R. F., Cliffel, D. \& Bard, A. J. (1998). Scanning Electrochemical Microscopy. 37. Light Emission by Electrogenerated Chemiluminescence at SECM Tips and Their Application to Scanning Optical Microscopy. Anal.Chem., Vol. 70, No. 14, (July 1998), pp. 2941-2948, ISSN 0003-2700

Feng, H., Wang, H., Zhang, Y., Yan, B. N., Shen, G. L. \& Yu, R. Q. (2007). A Direct Electrochemical Biosensing Platform Constructed by Incorporating Carbon Nanotubes and Gold Nanoparticles onto Redox Poly(thionine) Film. Anal. Sci., Vol. 23, No. 2, (February 2007), pp. 235-239, ISSN 0910-6340

Gavalas, V. G. \& Chaniotakis, N. A. (2000). Polyelectrolyte stabilized oxidase based biosensors: effect of diethylaminoethyl-dextran on the stabilization of glucose and lactate oxidases into porous conductive carbon. Anal. Chim. Acta, Vol. 404, No. 1, (January 2000), pp. 67-73, ISSN 0003-2670

Gavalas, V. G. \& Chaniotakis, N. A. (2001). Phosphate biosensor based on polyelectrolytestabilized pyruvate oxidase. Anal. Chim. Acta, Vol. 427, No. 2, (January 2001), pp. 271-277, ISSN 0003-2670

Guan, W. J., Li, Y., Chen, Y. Q., Zhang, X. B. \& Hu, G. Q. (2005). Glucose biosensor based on multi-wall carbon nanotubes and screen printed carbon electrodes. Biosens. Bioelectron., Vol. 21, No. 3, (September 2005), pp. 508-512, ISSN 0956-5663

Guo, C., Hu, F., Li, C. M. \& Shen, P. K. (2008). Direct electrochemistry of hemoglobin on carbonized titania nanotubes and its application in a sensitive reagentless hydrogen peroxide biosensor. Biosens. Bioelectron., Vol. 24, No. 4, (December 2008), pp. 819824, ISSN 0956-5663

Habrioux, A., Sibert, E., Servat, K., Vogel, W., Kokoh, K. B. \& Alonso-Vante, N. (2007). Activity of Platinum-Gold Alloys for Glucose Electrooxidation in Biofuel Cells. J. Phys. Chem. B, Vol. 111, No. 34, (August 2007), pp. 10329-10333, ISSN 1089-5647

Hashimoto, K., Ito, Y. \& Ishimori, Y. (1994). Novel DNA sensor for electrochemical gene detection. Anal. Chim. Acta, Vol. 286, No. 2, (February 1994), pp. 219-224, ISSN 00032670

Hsu, N. Y., Chien, C. C. \& Jeng, K. T. (2008) Characterization and enhancement of carbon nanotube-supported PtRu electrocatalyst for direct methanol fuel cell applications. Appl. Catal., B: Environ., Vol. 84, No. 1-2, (October 2008), pp. 196-203, ISSN 09263373 
Huang, C. P., Li, Y. K. \& Chen, T. M. (2007). A highly sensitive system for urea detection by using CdSe/ZnS core-shell quantum dots. Biosens. Bioelectron., Vol. 22, No. 8, (March 2007), pp. 1835-1838, ISSN 0956-5663

Hwang, C. G., Kim, S. H., Oh, J. H., Kim, M. R. \& Choi, S. H. (2008). Reduction of Aromatic Nitro Compounds on Pd Colloids Prepared by $\gamma$-Irradiation. J. Industr. Eng.Chem., Vol. 14, No. 6, (November 2008), pp. 864-868, ISSN 1226-086X

Hyeon, T., Han, S., Sung, Y., Park, K. \& Kim, Y. (2003). High-Performance Direct Methanol Fuel Cell Electrodes using Solid-Phase-Synthesized Carbon Nanocoils. Angew. Chem. Int. Ed., Vol. 42, No. 36, (September 2003), pp. 4352-4356, ISSN 0926-3373

Islam, M. F., Rojas, E., Bergey, D. M., Johnson, A. T. \& Yodh, A. G. (2003). High Weight Fraction Surfactant Solubilization of Single-Wall Carbon Nanotubes in Water. Nano Letters, Vol. 3, No. 2, (February 2003), pp. 269-273, ISSN 1530-6984

Jelly, R., Lewis, S. W., Lennard, C., Lim, K. F. \& Almog, J. (2008). Lawsone: a novel reagent for the detection of latent fingermarks on paper surfaces. Chem. Commun., Vol. 2008, No. 30, (August 2008), pp. 3513-3515, ISSN 1364-548X

Jia, J. B., Wang, B. Q., Wu, A. G., Cheng, G. J., Li, Z. \& Dong, S. J. (2002). A Method to Construct a Third-Generation Horseradish Peroxidase Biosensor: Self-Assembling Gold Nanoparticles to Three-Dimensional Sol-Gel Network. Anal. Chem., Vol. 74, No. 9, (May 2002), pp. 2217-2223, ISSN 0003-2700

Jung, D. J., Piao, M. H., Oh, S. H., Woo, J. C. \& Choi, S. H. (2010). Fabrication of Chemiluminescence Sensor Based on Conducting Polymer@SiO $/ \mathrm{Nafion}$ Composite Film. J. Nanosci. Nanotechnol., Vol. 10, No. 10, (October 2010), pp. 68556858, ISSN 1533-4880

Kang, Y. \& Taton, T. A. (2003). Micelle-Encapsulated Carbon Nanotubes: A Route to Nanotube Composites. J. Am. Chem. Soc., Vol. 125, No. 19, (April 2003), pp. 56505651, ISSN 0002-7863

Kim, K. I., Kang, H. Y., Lee, J. C. \& Choi, S. H. (2009). Fabrication of MWNT ion liquid electrode and its application for sensing phenolics in red wines. Sensors, Vol. 9, No. 9, (August 2009), pp. 6701-6714, ISSN 1424-8220

Kim, K. I., Lee. J. C., Kevin, R. \& Choi, S. H. (2010). Immobilization of tyrosinase in carboxylic- and carbonyl group-modified MWNT electrode and its application for sensing phenolics in red wines. J. Nanosci. Nanotechnol., Vol. 10, No. 6, (June 2010), pp. 3790-3798, ISSN 1533-4880

Kim, M. R. \& Choi, S. H. (2009). One-Pot Synthesis of Pd-M/ZnO (M = Ag, Cu, and Ni) Catalysts by $\gamma$-Irradiation and Their Use in Hydrogenation and Suzuki Reaction. J. Nanomaterials, Vol. 2009, (February 2009), pp. 1-7, ISSN 1687-4110

Kim, O. K., Je, J., Baldwin, J. W., Kooi, S., Pehrsson, P. E. \& Buckley, L. J. (2003). Solubilization of Single-Wall Carbon Nanotubes by Supramolecular Encapsulation of Helical Amylose. J. Am. Chem. Soc., Vol. 125, No. 15, (March 2003), pp. 4426-4427, ISSN 0002-7863

Kim, S. H., Oh, J. H., Yoo, B., Jung, D. J., Piao, M. H. \& Choi, S. H. (2008). Fabrication of Chemiluminescence Sensor Based on the Funcinalized MWNT-Nafion Composite Film. Adv. Mater. Res., Vol. 47-50, (June 2008), pp. 1474-1477, ISSN 1022-6680 
Kim, S. J., Oh, S. D., Lee, S. \& Choi, S. H. (2008). Radiolytic Synthesis of Pd-M (M = Ag, Ni, and $\mathrm{Cu} / \mathrm{C}$ Catalyst and Their Use in Suzuki-type and Heck-type Reaction. J. Industr. Eng. Chem., Vol. 14, No. 4, (July 2008), pp. 449-456, ISSN 1226-086X

Kim, S. K., Ryu, J. H., Kwen. H. D. \& Choi, S. H. (2010). Convenient Preparation of IonExchange PVdF Membrane by Radiation-Induced Graft Polymerization for a Battery Separator. Polymer(Korea), Vol. 34, No. 2, (March 2010), pp. 126-132, ISSN 0379-153X

Kim, S. K., Kwen, H. D. \& Choi, S. H. (2011). Fabrication of microbial biosensor based on the QDs-MWNTs supports by one-step radiation reaction and detection of phenolic compounds in red wines. Sensors, vol. 11, (January 2011), pp. 2001-2012, ISSN 14248220

Kitano, H., Tachimoto, K. \& Anraku,Y. (2007). Functionalization of single-walled carbon nanotube by the covalent modification with polymer chains. J. Colloid Interface Sci., Vol. 306, No. 1, (February 2007), pp. 28-33, ISSN 0021-9797

Knight, A. W. (1999). A review of recent trends in analytical applications of electrogenerated chemiluminescence. Trends Anal. Chem., Vol. 18, No. 1, (January 1999), pp. 47-62, ISSN 0165-9936

Koide, S. \& Yokoyama, K. (1999). Electrochemical characterization of an enzyme electrode based on a ferrocene-containing redox polymer. J. Electroanal. Chem., Vol. 468, No. 2, (June 1999), pp. 193-201, ISSN 0022-0728

Kooi, S. E., Schlecht, U., Burghard, M. \& Kern, K. (2002). Electrochemical Modification of Single Carbon Nanotubes. Angew. Chem. Int. Ed., Vol. 41, No. 8, (April 2002), pp. 1353-1355, ISSN 1521-3773

Kranaster, R. \& Marx, A. (2007). Increased single-nucleotide discrimination in allele-specific polymerase chain reactions through primer probes bearing nucleobase and 2'deoxyribose modifications. Chem. Eur. J., Vol. 13, No. 21, (July 2007), pp. 6115-6122, 1521-3765

Kwon, S. Y., Whittaker, A. \& Choi, S. H. (2011). Fabrication of non-enzymatic glucose sensor based on MWNTs with bimetallic Pt-M (M= Ru and Sn) catalysts by radiolytic deposition. Biosens. Bioelectron., submitted for publication (2010-11-08), ISSN 09565663

Lee, Y. J., Kim, J. D. \& Park, J. Y. (2009). CMOS-Integrable Enzyme-Free Amperometric Cholesterol Nano-Biosensor for U-Health and POC Applications. Journal of the Korean Physical Society, Vol. 54, No. 5, (May 2009), pp. 1769-1773, ISSN 0374-4884

Lee, Y. J. \& Choi, S. H. (2010). Electrochemical phenol biosensor based on immobilization of tyrosinase on poly(GMA-co-VFc)/MWNT electrode. Proceedings of the Korean society of analytical sciences, Jeju, Korea, November 2010

Lei, Y., Chen, W. \& Mulchandani, A. (2006). Microbial biosensors. Anal. Chim. Acta, Vol. 568, No. 1-2, (May 2006), pp. 200-210, ISSN 0003-2670

Li, Y., Kotzeva, V. P. \& Fray, D. J. (2006). Electrochemical performance of CdS nanomaterials synthesized by microemulsion techniques. Materials Letters, Vol. 60, No. 21-22, (September 2006), pp. 2743-2746, ISSN 0167-577X

Lin, K. C., Tsai, T. S., \& Chen, S. M. (2010). Performing enzyme-free $\mathrm{H}_{2} \mathrm{O}_{2}$ biosensor and simultaneous determination for AA, DA, and UA by MWNT-PEDOT film. Biosens. Bioelectron., Vol. 26, No. 2, (October 2010), pp. 608-614, ISSN 0956-5663 
Lin, M. S. \& Leu, H. J. (2005). A Fe $\mathrm{O}_{4}$-Based Chemical Sensor for Cathodic Determination of Hydrogen Peroxide. Electroanalysis, Vol. 17, No. 22, (November 2005), pp. 20682073, ISSN 1521-4109

Liu, H., Mao, G. \& Meng, S. (1992). Preparation and characterization of the polymerprotected palladium - gold colloidal bimetallic catalysts. J. Mol. Catal., Vol. 74, No. 1-3, (July-August 1992), pp. 275-284, ISSN 1381-1169

Liu, P. (2005). Modifications of carbon nanotubes with polymers. Eur. Polym. J., Vol. 41, No. 11, (November 2005), pp. 2693-2703, ISSN 0014-3057

Male, K. B., Hrapovic, S. \& Luong, J. H. T. (2007). Electrochemically-assisted deposition of oxidases on platinum nanoparticle/multi-walled carbon nanotube-modified electrodes. Analyst, Vol. 132, No. 12, (December 2007), pp. 1254-1261, ISSN 00032654

Marras, S. A. E., Tyagi, S. \& Kramer, F. R. (2006). Real-time assays with molecular beacons and other fluorescent nucleic acid hybridization probes. Clin. Chim. Acta, Vol. 363, No. 1-2, (January 2006), pp. 48-60, ISSN 0009-8981

Men, X. H., Zhang, Z. Z., Song, H. J., Wang, K. \& Jiang, W. (2008). Functionalization of carbon nanotubes to improve the tribological properties of poly(furfuryl alcohol) composite coatings. Comp. Sci. Technol., Vol. 68, No. 3-4, (March 2008), pp. 10421049, ISSN 0266-3538

Millan, K. M., Saraullo, A. \& Mikkelsen, S. R. (1994). Voltammetric DNA Biosensor for Cystic Fibrosis Based on a Modified Carbon Paste Electrode. Anal. Chem., Vol. 66, No. 18, (September 1994), pp. 2943-2948, ISSN 0003-2700

Musameh, M., Wang, J., Merkoci, A. \& Lin, Y. (2002). Low-potential stable NADH detection at carbon-nanotube-modified glassy carbon electrodes. Electrochem. Commun., Vol. 4, No. 10, (October 2002), pp. 743-746, ISSN 1388-2481

Niu, S. Y., Wu, M. L., Hu, L. Z., Mei, Z. H. \& Liu, S. F. (2009). Nucleic acid biosensor for DNA hybridization detection using rutin- $\mathrm{Cu}$ as an electrochemical indicator. Electrochimica Acta, Vol. 54, No. 5, (February 2009), pp. 1564-1569, ISSN 0013-4686

Noffsinger, J. B. \& Danielson, N. D. (1987). Liquid chromatography of aliphatic trialkylamines with post-column chemiluminescent detection using tris(2,2'bipyridine)ruthenium(III). J. Chromatorgr. A, Vol. 387, (March 1987), pp. 520-524, ISSN 0021-9673

Odaci, D., Timur, S. \& Telefoncu, A. (2008). Bacterial sensors based on chitosan matrices. Sens. Actuators B, Vol. 134, No. 1, (August 2008), pp. 89-94, ISSN 0925-4005

Oh, S. D., So, B. K., Choi, S. H., Gopalan, A., Lee, K. P., Yoon, K. R. \& Choi, I. S. (2005). Dispersing of $\mathrm{Ag}, \mathrm{Pd}$, and $\mathrm{Pt}-\mathrm{Ru}$ alloy nanoparticles on single-walled carbon nanotubes by $\gamma$-irradiation, Materials Letters, Vol. 59, No. 10, (April 2005), pp. 11211124, ISSN 0167-577X

Oh, S. D., Choi, S. H., Gopalan, A., Lee, K. P. \& Kim, S. H. (2006a). Radiolytic Functionalization of Single- and Multi-Walled Carbon Nanotubes. J. Industr. Eng. Chem., Vol. 12, No. 1, (January 2006), pp. 156-160, ISSN 1226-086X

Oh, S. D., Yoon, K. R., Choi, S. H., Gopalan, A., Lee, K. P., Sohn, S. H., Kang, H. D. \& Choi, I. S. (2006b). Dispersion of Pt-Ru alloys onto various carbons using $\mathrm{Y}$-irradiation, $J$. Non-Cryst. Solids, Vol. 352, No. 4, (April 2006), pp. 355-360, ISSN 0022-3093 
Oh, S. D., Kim, M. R., Choi, S. H., Chun, J. H., Lee, K. P., Gopalan, A. I., Hwang, C. G., Kim, S. H. \& Oh, J. H. (2008). Radiolytic Synthesis of Pd-M (M = Ag, Au, Cu, Ni and Pt) Alloy Nanoparticles and Its Use in Reduction of 4-Nitrophenol. J. Industr. Eng.Chem., Vol. 14, No. 5, (September 2008), pp. 687-692, ISSN 1226-086X

Park, K., Choi, J. H., Ahn, K. S. \& Sung, Y. E. (2004). PtRu Alloy and PtRu-WO Nanocomposite Electrodes for Methanol Electrooxidation Fabricated by a Sputtering Deposition Method. J. Phys. Chem. B, Vol. 108, No. 19, (May 2004), pp. 5989-5994, ISSN 1089-5647

Park, S. J., Chung, T. D. \& Kim, H. C. (2003). Nonenzymatic Glucose Detection Using Mesoporous Platinum. Anal. Chem., Vol. 75, No. 13, (July 2003), pp. 3046-3049, ISSN 0003-2700

Patolsky, F., Weizmann, Y. \& Willner, I. (2004). Long-Range Electrical Contacting of Redox Enzymes by SWCNT Connectors. Angew. Chem. Int. Ed., Vol. 43, No. 16, (April 2004), pp. 2113-2117, ISSN 1521-3773

Piao, M. H., Yang, D. S., Yoon, K. R., Lee, S. H. \& Choi, S. H. (2009). Development of an Electrogenerated Chemiluminescence Biosensor using Carboxylic acidfunctionalized MWNT and Au Nanoparticles. Sensors, Vol. 9, No. 3, (March 2009), pp. 1662-1677, ISSN 1424-8220

Piao, M. H., Son, P. S., Chang, C. H. \& Choi, S. H. (2010). A glucose biosensor based on deposition of glucose oxidase onto $\mathrm{Au}$ nanoparticles poly(maleic anhydride)grafted multiwalled carbon nanotube electrode. Anal. Sci. Tech., Vol. 23, No. 2, (April 2010), pp. 165-171, ISSN 1225-0163

Qu, L. T., Dai, L. M. \& Osawa, E. (2006). Shape/Size-Controlled Syntheses of Metal Nanoparticles for Site-Selective Modification of Carbon Nanotubes. J. Am. Chem. Soc., Vol. 128, No. 16, (April 2006), pp. 5523-5532, ISSN 0002-7863

Reddy, A. L. M. \& Ramaprabhu, S. (2007). Pt/SWNT-Pt/C Nanocomposite Electrocatalysts for Proton-Exchange Membrane Fuel Cells. J. Phys. Chem. C, Vol. 111, No. 44, (November 2007), pp. 16138-16146, ISSN 1932-7447

Ryu, H. N. \& Choi, S. H. (2010a). Tyrosinase-immobilized Biosensor Based on Ionic Property-modified MWNTs Prepared by Radiation-induced Graft Polymerization. Carbon Letters, Vol. 11, No. 3, (December 2010), pp. 216-223, ISSN 1976-4251

Ryu, H. N. \& Choi, S. H. (2010b). Fabrication of electrochemiluminescence (ECL) sensor based on sulfonic acid $\left(-\mathrm{SO}_{3} \mathrm{H}\right)$ functionalized carbon nanotube. Proceedings of the Korean society of analytical sciences, Jeju, Korea, November 2010

Saito, T. \& Watanabe, M. (1998). Characterization of poly(vinylferrocene-co-2- hydroxyethyl methacrylate) for use as electron mediator in enzymatic glucose sensor. React. Funct. Polym., Vol. 37, No. 1-3, (June 1998), pp. 263-269, ISSN 1381-5148

Saito, Y., Yoshikawa, T., Okuda, M., Fujimoto, N., Sumiyama, K., Suzuki, K., Kasuya, A. \& Nishina, Y. (1993). Carbon nanocapsules encaging metals and carbides. J. Phys. Chem. Solids., Vol. 54, No. 12, (December 1993), pp. 1849-1860, ISSN 0022-3697

Seo, K. D., Oh, S. D., Choi, S. H., Kim, S. H., Park, H. G. \& Zhang, Y. P. (2008). Radiolytic loading of the $\mathrm{Pt}-\mathrm{Ru}$ nanoparticles onto the porous carbons. Colloids Surf. A: Physicochem. Eng. Aspects, Vol. 313-314, (February 2008), pp. 393-397, ISSN 09277757 
Shen, J., Huang, W., Wu, L., Hu, Y. \& Ye, M. (2007). Study on amino-functionalized multiwalled carbon nanotubes. Mater. Sci. Eng. A, Vol. 464, No. 1-2, (August 2007), pp. 151-156, ISSN 0921-5093

Shen, X-C., Zhang, Z-L., Zhou, B., Peng, J., Xie, M., Zhang, M. \& Pang, D-W. (2008). Visible lightinduced plasmid DNA damage catalyzed by a CdSe/ZnS-photosensitized nano-TiO 2 film. Environ. Sci. Technol., Vol. 42, No. 14, (July 2008), pp. 5049-5054, ISSN 0013-936X

Shin, S. R., Kwen, H. D. \& Choi, S. H. (2011). Fabrication of Electrochemical Microbial Biosensor Based on MWNT Supports prepared by Radiation-Induced Graft Polymerization, Polymer(Korea), submitted for publication (2010-09), ISSN 0379153X

Shumyantseva, V., Deluca, G., Bulko, T., Carrara, S., Nicolini, C., Usanov, S. \& Archakov, A. (2004). Cholesterol amperometric biosensor based on cytochrome P450scc. Biosens. Bioelectron., Vol. 19, No. 9, (April 2004), pp. 971-976, ISSN 0956-5663

Song, Y. Y., Zhang, D., Gao, W. \& Xia, X. H. (2005). Nonenzymatic Glucose Detection by Using a Three-Dimensionally Ordered, Macroporous Platinum Template, Chem. Eur. J., Vol. 11, No. 7, (March 2005), pp. 2177-2182, ISSN 1521-3765

Steigerwalt, E. S., Deluga, G. A. \& Lukehart, C. M. (2002). Pt-Ru/Carbon Fiber Nanocomposites: Synthesis, Characterization, and Performance as Anode Catalysts of Direct Methanol Fuel Cells. A Search for Exceptional Performance. J. Phys. Chem. B, Vol. 106, No. 4, (January 2002), pp. 760-766, ISSN 0022-3654

Sun, Y., Buck, H. \& Mallouk, T. E. (2001). Combinatorial Discovery of Alloy Electrocatalysts for Amperometric Glucose Sensors. Anal. Chem., Vol. 73, No. 7, (April 2001), pp. 1599-1604. ISSN 0003-2700

Sweeny, B. K. \& Peters, G. G. (2001). Cyclic voltammetric study of the catalytic behavior of nickel (I) salen electrogenerated at a glassy carbon electrode in an ionic liquid (1butyl-3-methylimidazolium tetrafluoroborate, BMIM+BF4-). Electrochem. Commun., Vol. 3, No. 12, (December 2001), pp. 712-715, ISSN 1388-2481

Tasis, D., Tagmatarchis, N., Georgakilas, V. \& Prato, M. (2003). Soluble Carbon Nanotubes. Chem. Eur. J., Vol. 9, No. 17, (September 2003), pp. 4000-4008, ISSN 0947-6539

Timko, M. P., Rushton, P. J., Laudeman, T. W., Bokowiec, M. T., Chipumuro, E., Cheung, F., Town, C. D. \& Chen, X. F. (2008). Sequencing and analysis of the gene-rich space of cowpea. BMC Genomics., Vol. 9, (February 2008), pp. 103-123, ISSN 1471-2164

Wang, J., Li, M., Shi, Z., Li, N. \& Gu, Z. (2002a). Electrocatalytic Oxidation of Norepinephrine at a Glassy Carbon Electrode Modified with Single Wall Carbon Nanotubes. Electroanalysis,Vol. 14, No. 3, (February 2002), pp. 225-230, ISSN 15214109

Wang, J., Li, M., Shi, Z., Li, N. \& Gu, Z. (2002b). Direct Electrochemistry of Cytochrome c at a Glassy Carbon Electrode Modified with Single-Wall Carbon Nanotubes. Anal. Chem., Vol. 74, No. 9, (March 2002), pp. 1993-1997, ISSN 0003-2700

Wang, J. \& Musameh, M. (2003a). Carbon Nanotube/Teflon Composite Electrochemical Sensors and Biosensors. Anal. Chem., Vol. 75, No. 9, (March 2008), pp. 2075-2079, ISSN 0003-2700 
Wang, J., Musameh, M. \& Lin, Y. (2003b). Solubilization of Carbon Nanotubes by Nafion toward the Preparation of Amperometric Biosensors. J. Am. Chem. Soc., Vol. 125, No. 9, (February 2003), pp. 2408-2409, ISSN 0002-7863

Wang, J., Jina, S. \& Wang, B. (2005). A new boronic acid fluorescent reporter that changes emission intensities at three wavelengths upon sugar binding. Tetrahedron Lett., Vol. 46, No. 41, (October 2005), pp. 7003-7006, ISSN 0040-4039

Wang, J., Thomas, D. F. \& Chen, A. (2008). Nonenzymatic Electrochemical Glucose Sensor Based on Nanoporous PtPb Networks. Anal. Chem., Vol. 80, No. 4, (February 2008), pp. 997-1004, ISSN 0003-2700

Wang, S. F., Wang, W. \& Cai, H. C. (2005). Recognition and detection of dsDNA at a thionalid self-assembled monolayer modified gold electrode. Sens. Actuator B: Chem., Vol. 104, No. 1, (January 2005), pp. 8-14, ISSN 0925-4005

Wang, Y., Huang, J., Zhang, C., Wei, J. \& Zhou, X. (1998). Determination of Hydrogen Peroxide in Rainwater by Using a Polyaniline Film and Platinum Particles CoModified Carbon Fiber Microelectrode. Electroanalysis, Vol. 10, No. 11, (September 1998), pp. 776-778, ISSN 1521-4109

Wang, Z. H., Liu, J., Liang, Q. L., Wang, Y. M. \& Luo, G. (2002). Carbon nanotube-modified electrodes for the simultaneous determination of dopamine and ascorbic acid. Analyst, Vol. 127, No. 5, (May 2002), pp. 653-658, ISSN 0003-2654

Wightman, R. M., Curtis, C. L., Flowers, P. A., Maus, R. G. \& McDonald, E. M. (1998). Imaging Microelectrodes with High-Frequency Electrogenerated Chemiluminescence. J. Phys. Chem. B., Vol. 102, No. 49, (December 1998), pp. 99919996, ISSN 1089-5647

Xiao, F., Zhao, F., Zhang, Y., Guo, G. \& Zeng, B. (2009). Ultrasonic Electrodeposition of Gold-Platinum Alloy Nanoparticles on Ionic Liquid-Chitosan Composite Film and Their Application in Fabricating Nonenzyme Hydrogen Peroxide Sensors. J. Phys. Chem. C, Vol. 113, No. 3, (January 2009), pp. 849-855, ISSN 1932-7447

Yang, D. S., Jung, D. J. \& Choi, S. H. (2010). One-step functionalization of multi-walled carbon nanotubes by radiation-induced graft polymerization and their application as enzyme-free biosensors. Radia. Phys. Chem., Vol. 79, No. 4, (April 2010), pp. 434440, ISSN 0969-806X

Yang, D. S., Sim, K. S., Kwen, H. D. \& Choi, S. H. (2011). Radiolytic synthesis of Pt-Ru catalysts based on functional polymer-grafted MWNT and their catalytic efficiency for CO and MeOH. J. Nanomaterials, Vol. 2011, pp. 1-8, ISSN 1687-4110

Yang, J. H., Lee, J. C. \& Choi, S. H. (2009). Tyrosinase-Immobilized Biosensor Based on the Functionalized Hydroxyl Group-MWNT and Detection of Phenolic Compounds in Red Wines. J. Sensors, Vol. 2009, (August 2009), pp. 1-9, ISSN 1687-725X

Yang, R., Qiu, X., Zhang, H., Li, J., Zhu, W., Wang, Z., Huang, X. \& Chen, L. (2005). Monodispersed hard carbon spherules as a catalyst support for the electrooxidation of methanol. Carbon, Vol. 43, No. 1, (January 2005), pp. 11-16, ISSN 0008-6223

Yu, W., Liu, M., Liu, H. \& Zheng, J. (1999). Preparation of Polymer-Stabilized Noble Metal Colloids. J. Colloid Interf. Sci., Vol. 210, No. 1, (February 1999), pp. 218-221, ISSN 0021-9797

Zhang, L. \& Fang, M. (2010). Nanomaterials in pollution trace detection and environmental improvement. Nano Today, Vol. 5, No. 2, (April 2010), pp. 128-142, ISSN 1748-0132 
Zhang, Y. J., Shen, Y. F., Li, J. H., Niu, L., Dong, S. J. \& Ivaska, A. (2005). Electrochemical Functionalization of Single-Walled Carbon Nanotubes in Large Quantities at a Room-Temperature Ionic Liquid Supported Three-Dimensional Network Electrode. Langmuir, Vol. 21, No. 11, (May 2005), pp. 4797-4800, ISSN 0743-7463

Zhao, Y., Zheng, W. D., Chen, H. \& Luo, Q. M. (2002). Anodic oxidation of hydrazine at carbon nanotube powder microelectrode and its detection. Talanta, Vol. 58, No. 3, (September 2002), pp. 529-534, ISSN 0039-9140 


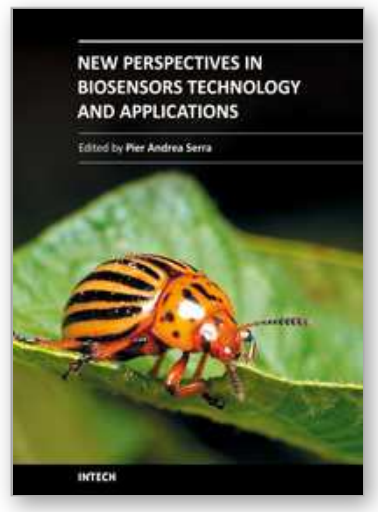

\author{
New Perspectives in Biosensors Technology and Applications \\ Edited by Prof. Pier Andrea Serra
}

ISBN 978-953-307-448-1

Hard cover, 448 pages

Publisher InTech

Published online 27, July, 2011

Published in print edition July, 2011

\begin{abstract}
A biosensor is a detecting device that combines a transducer with a biologically sensitive and selective component. Biosensors can measure compounds present in the environment, chemical processes, food and human body at low cost if compared with traditional analytical techniques. This book covers a wide range of aspects and issues related to biosensor technology, bringing together researchers from 12 different countries. The book consists of 20 chapters written by 69 authors and divided in three sections: Biosensors Technology and Materials, Biosensors for Health and Biosensors for Environment and Biosecurity.
\end{abstract}

\title{
How to reference
}

In order to correctly reference this scholarly work, feel free to copy and paste the following:

Da-Jung Chung, Hae-Doo Kwen and Seong-Ho Choi (2011). Fabrication of biosensors using vinyl polymergrafted carbon nanotubes, New Perspectives in Biosensors Technology and Applications, Prof. Pier Andrea Serra (Ed.), ISBN: 978-953-307-448-1, InTech, Available from: http://www.intechopen.com/books/newperspectives-in-biosensors-technology-and-applications/fabrication-of-biosensors-using-vinyl-polymer-graftedcarbon-nanotubes

\section{INTECH}

open science | open minds

\section{InTech Europe}

University Campus STeP Ri

Slavka Krautzeka 83/A

51000 Rijeka, Croatia

Phone: +385 (51) 770447

Fax: +385 (51) 686166

www.intechopen.com

\section{InTech China}

Unit 405, Office Block, Hotel Equatorial Shanghai

No.65, Yan An Road (West), Shanghai, 200040, China

中国上海市延安西路65号上海国际贵都大饭店办公楼405单元

Phone: +86-21-62489820

Fax: +86-21-62489821 
(C) 2011 The Author(s). Licensee IntechOpen. This chapter is distributed under the terms of the Creative Commons Attribution-NonCommercialShareAlike-3.0 License, which permits use, distribution and reproduction for non-commercial purposes, provided the original is properly cited and derivative works building on this content are distributed under the same license. 